\title{
Analysis of Physical and Chemical Water Quality (Sekanak River in Lowlands Area) to Support the Palembang City Government Revitalization Program
}

\author{
$1^{\text {st }}$ Pra Dian Mariadi \\ Department of Medical Laboratory Technology \\ Musi Charitas Catholic University \\ Palembang, Indonesia \\ pradian@ukmc.ac.id
}

\author{
$2^{\text {nd }}$ Ian Kurniawan \\ Department of Medical Laboratory Technology \\ Musi Charitas Catholic University \\ Palembang, Indonesia \\ iankurniawan019@gmail.com
}

Corresponding author: iankurniawan019@gmail.com

\begin{abstract}
The revitalization of the Sekanak River is one of the Palembang city government programs. Sekanak River is one of the oldest rivers in the city of Palembang that receives waste, from both industry and domestic so that the quality will experience pollution. The development of activities along the Sekanak River has affected river water quality. Decreased river water quality can be qualitative identified with the occurrence of changes in colour and odour. Some communities in the watershed area still use it for their daily needs. The current problem of decreasing the quality of river water in Sekanak requires chemical and physical examinations to anticipate the effects of environmental pollution. The study was conducted using a sample of water from the Sekanak River taken at 2 sample points close to human activities. The results showed that sample 1 showed several parameters that exceeded the quality standard while sample 2 that was located creek area was still in good condition. The physical parameters of the river point 1 water sample exceed the allowable limits for the Total Suspended Solids (TSS) and Total Dissolved Solids (TDS) parameters. For inorganic chemical parameters, the water sample at point 1 exceeds the allowed limits for the parameters of $\mathrm{pH}$, ferrous $(\mathrm{Fe})$ and lead $(\mathrm{Pb})$ and sulphate ion content (SO4).
\end{abstract}

Keywords: Sekanak River, Water quality, Physical, Chemical.

\section{INTRODUCTION}

World Water Forum II in Den Haag in March 2000 has predicted that clean[1] water services for the community are still difficult to implement and Indonesia is one of the countries experiencing water crisis in 2025 . Increased human activity, changes in land use and increasingly diverse patterns of life of urban communities that produce domestic waste make the burden of pollutants on the river greater over time. Water quality degradation occurs because of uncontrolled waste disposal from development activities along the river so it is not in accordance with the carrying capacity of the river.

Indonesia has the river area lowlands widest in the world that is 20.6 million hectares (approximately $10.8 \%$ of Indonesia land area). In this area, around $35 \%(+7.2$ million hectares) found on the island of Sumatera [2]. In this area, there are many community settlements. Communities living in the lowlands are generally very difficult to get clean water. Organic substances with water brownish red color and high acidity [3] have contaminated clean water in this region.

In general, rivers in the lowlands is peat which is formed from an organic substance, but there are also inorganic substances but in small qualities. The main elements forming peat are carbon $(\mathrm{C})$, hydrogen $(\mathrm{H})$, nitrogen $(\mathrm{N})$ and oxygen

(O). These elements will form larger molecules such as humic acid, fulvic acid, cellulose, protein, lignin and bitumen [4]. Peatlands formed from heaps of organic 
matter, so that thecarbon content in peat soils is very large.

Organic fraction in Indonesia is more than $95 \%$, the rest is inorganic fraction which is less than $5 \%$. The organic fraction consists of humic compounds around $10-20 \%$ and compounds of non-humic compounds that include lignin, cellulose, hemicellulose, wax, tannin, resin and a small amount of protein [5]. Main compounds forming peat the common are humid acid and folic acid, which are colloidal, amorphous, dark brown polymers. In the peat deposition environment, more than $90 \%$ are in a state of water saturation, some organic compounds will dissolved and dispersed which causes peat water to be dark brown.

Musi River is a river that has become the estuary are dozens of other large and small rivers with length of around $720 \mathrm{~km}$ and crosses the city of Palembang. Various activities in industries such as mining, plantation, agriculture, household activities, as well as a natural activity that goes into this river waters have an impact on the biota leeks and health. The activity also resulted in the exposure of heavy metals into river bodies [6]. Sekanak River is one of the rivers that flow in Palembang City that receives waste, both from industry and domestic. The development of industries and settlements along the Sekanak river flow has affected river water quality. The environment can be said to be polluted if it is entered or the introduction of pollutants that can cause interference with living things in it [7]. The decline in water quality marked by changes in the colour of the water and smell even though some people on the riverbanks still use the Sekanak River water for their daily needs.

One of the river be polluted if the quality of the water is not in accordance with the designation. Water quality standards according to river class based on Government Regulation No. 82 of 2001 concerning Management of water quality and water Pollution Control. Land use is an important part that has an influence on river water quality. The ability of river water capacity that already exists naturally to pollution needs to maintain to minimize the occurrence of river quality degradation [8]. Land use along the Sekanak River that can affect river water quality includes settlements and industry. Community activities that produce domestic wastewater discharges as well as the presence of the textile industry, songket, tofu, tempe and others that dispose of their waste water into the Sekanak river will affect water quality. Water quality management is carried out by efforts to control water pollution, namely by efforts to maintain the function of water so that the water quality meets quality standards [9].
The decline in the quality of the Musi River and its watershed occurred towards 1980. The Musi River began to lose its function due to water pollution, either due to factory waste, mine waste or due to household waste. Eventually, the loss of this function was followed by the loss of the river in the hearts of the people. Palembang people's awareness to maintain river cleanliness has continued to decline in the last 40 years, as evidenced by the rise of garbage dumping into rivers, river silting, river narrowing, followed by the loss of several Musi tributaries due to a combination of these factors. During its time, the Sekanak River once connected the Musi River and the Siguntang Hill, while now the rivers is no more than two kilometers long due to the disappearance of the upper reaches of the river due to landfill activity. An analysis of the quality of the Metro river in Malang and obtained from 3 locations of sampling points with criteria exceeding the TSS and BOD quality standards at point 1 and moderately polluted at points 2 and 3 [10]. Analyzed Temperature, TSS, pH, DO, BOD, COD, Chromium and Phosphate parameters at 6 sampling points in the Kupang River, Pekalongan where BOD levels at all points have exceed the quality standards and COD at only a few points [11].

Sekanak River is one of the Musi River tributaries that is risk of polluted. Besides causing unpleasant odors, garbage is floating in the river's flow. Plastic, wood, leaf, and other trash drifted along the flow to the Musi River. Although the water is pitch, some people, especially children, for bathing, still often use black, the river. Sekanak River is a river located in an urban area that is very vulnerable to pollution from industrial and household waste. However, some residents who live in the second river area still use the river, especially for bathing children. Sekanak River is one of the Musi River tributaries that is at risk of polluted. Besides causing unpleasant odors, garbage is floating in the river's flow. Plastic, wood, leaf, and other trash drifted along the flow to the Musi River. Although the water is pitch, some people especially children, for bathing, still often use black, the river. The use of Sekanak river water in fulfilling the daily activities of the population will have a short and long-term impact if there are no current data on the status of the Sekanak River water quality. Sekanak River is a regional government program in Palembang city to be revitalize and improved in both quantity and quality.

\section{METHODS}

\section{A. Types of Research}

The study was conducted using a quantitative descriptive approach. Descriptive method with a 
quantitative approach in this study was used to describe the condition of the Sekanak river water quality from residential and industrial activities.

\section{B. Research Time}

This research was conducted in March or August 2019. The length of the Sekanak river as a research location along $\pm 2 \mathrm{~km}$ located in the city of Palembang.

\section{Research Sampling Locations}

The water quality research was carried out at two monitoring points by dividing into two segments, determining monitoring points as river water sampling points using a purposive sampling method based on case of access, cost and time in this study. The initial assumption in this study will be use 2 sampling points at the Radial Street (Fig.1) and creek points of the Sekanak River (Fig.2).

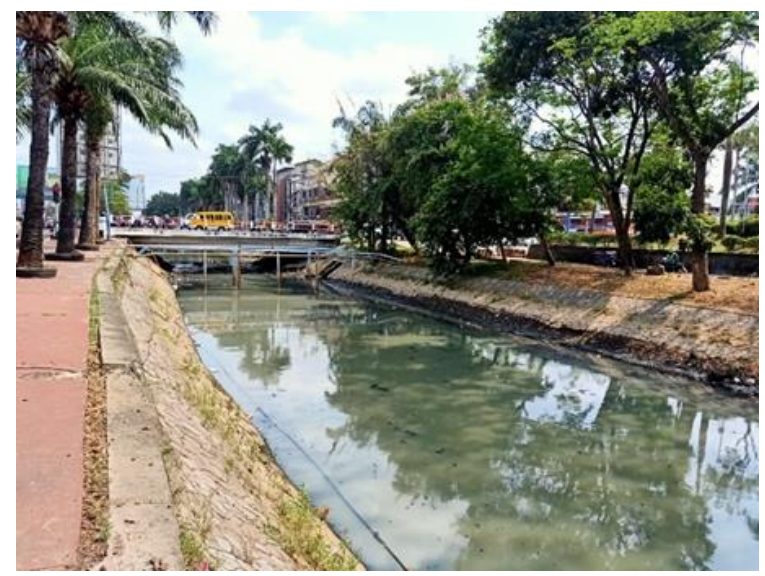

Fig. 1. Sampling points at Radial Street (Sampling 1)

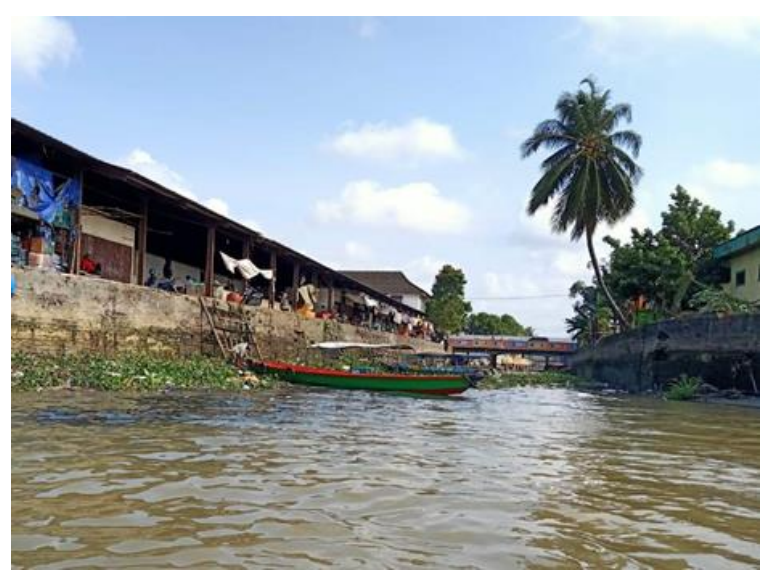

Fig.2. Sampling Point at Creek (Sampling 2)

\section{Research Sampling}

The river water sampling method that is carried out directly using the grab sampling method is a method of taking a momentary sample that shows the characteristics of the water only at that time by using a water sampler according to SNI 6989.59:2008. Before analyzed in a laboratory, preservation carried out so that there is no physical or chemical change. The parameters analyzed include the parameters of physics and organic chemistry.

\section{E. Methods of Data Collection and Analysis}

Data collection techniques carried out by observation, laboratory analysis, documentation and a combination technique.

a. Field observations and measurements of river water quality carried out to directly observe community activities and analyze the condition of the study area including the measurement and recording of water discharge. Sampling for measurement of river water quality which is includes physical and chemical conditions

b. Laboratory analysis of river water samples includes physical and chemical analysis in accordance with South Sumatera Government Regulation No. 16 of 2005 concerning Designation of Water and River Water Quality Standards

c. Documentation used to describe the condition of the research location, land use and activities in the Sekanak River.

\section{RESULTS}

\section{A. Physics Parameters}

Physical water quality analysis includes several parameters, namely Temperature, total suspended solid (TSS) and total dissolve solid(TDS). For TSS examination using the standard method of SNI 6989.72.2009 and TDS inspection using U-10 Water Cracker. The results of the water physics test see in Table 1.

\begin{tabular}{|c|c|c|c|c|}
\hline $\begin{array}{c}\text { Physics } \\
\text { Parameters }\end{array}$ & $\mathbf{T L V}^{\mathrm{a}}$ & $\mathbf{A}$ & $\mathbf{B}$ & Test Method \\
\hline $\mathrm{T}\left({ }^{0} \mathrm{C}\right)$ & $\begin{array}{l}\text { Deviation } \\
3\end{array}$ & 27,8 & 25,2 & Instrumen \\
\hline TSS (mg/L) & 50 & 65 & 43 & SNI 6989.72.2009 \\
\hline TDS (mg/L) & 1000 & 1600 & 850 & Water Chacker U-10 \\
\hline \multicolumn{5}{|c|}{$\begin{array}{l}{ }^{a} \text { Regulation of the Governor of South Sumatra No. } 16 \text { of } 2005 \\
\text { concerning the Designation of Water and River Quality Raw } \\
\text { Water }{ }^{\text {and }} \text { Palembang Mayor Regulation No. } 2 \text { of } 2003 \text { concerning } \\
\text { River Water Quality Standards (Classes 1-4) and Liquid Waste } \\
\text { Quality Standards }\end{array}$} \\
\hline
\end{tabular}

\section{B. Chemical Parameters}

Analysis of water quality inorganic chemistry includes testing the quality of acidity $(\mathrm{pH})$, the content of metals such as iron $(\mathrm{Fe})$, hardness $(\mathrm{Mg})$, zinc $(\mathrm{Zn})$, and lead metal $(\mathrm{Pb}), \mathrm{N}$ content as nitrite and nitrate and anion content sulfate. Examination of inorganic chemical analysis by the spectrophotometric method except the degree of acidity carried out in the laboratory of the 
Faculty of Natural Sciences, Sriwijaya University. The results of the inorganic chemical quality analysis of the water samples in the Radial Street and Creek of the Sekanak Palembang see in Table 2.

Table 2. Results of chemical analysis

of inorganic samples of Sekanak river water

\begin{tabular}{|c|c|c|c|c|}
\hline $\begin{array}{c}\text { Chemical } \\
\text { Parameters }\end{array}$ & $\mathbf{T L V}^{\mathbf{a}}$ & $\mathbf{A}$ & $\mathbf{B}$ & Test Metho \\
\hline $\mathrm{pH}$ & $6-9$ & 5,2 & 6,8 & SNI 066 \\
\hline Iron $(\mathrm{Fe})$ & $0,3 \mathrm{mg} / \mathrm{L}$ & 0,45 & 0,23 & Spectrophoto \\
\hline $\begin{array}{l}\text { Manganese } \\
(\mathrm{Mn})\end{array}$ & $0,2 \mathrm{mg} / \mathrm{L}$ & 0,12 & 0,10 & Spectrophoto \\
\hline Nitrate as $\mathrm{N}$ & $10 \mathrm{mg} / \mathrm{L}$ & 8 & 8 & Spec \\
\hline Nitrite as $\mathrm{N}$ & $0,06 \mathrm{mg} / \mathrm{L}$ & 0,02 & 0,04 & Spe \\
\hline Zinc $(\mathrm{Zn})$ & $0,005 \mathrm{mg} / \mathrm{L}$ & 0,001 & 0 & \\
\hline Sulfate $\left(\mathrm{SO}_{4}\right)$ & $400 \mathrm{mg} / \mathrm{L}$ & 475 & 350 & Spe \\
\hline Lead $(\mathrm{Pb})$ & $0,03 \mathrm{mg} / \mathrm{L}$ & 0,085 & 0,040 & Spectrophoto \\
\hline \multicolumn{5}{|c|}{$\begin{array}{l}{ }^{a} \text { Regulation of the Governor of South Sumatra No. } 16 \text { of } 2005 \\
\text { concerning the Designation of Water and River Quality Raw } \\
\text { Water }{ }^{\text {and }} \text { Palembang Mayor Regulation No. } 2 \text { of } 2003 \text { concerning } \\
\text { River Water Quality Standards (Classes 1-4) and Liquid Waste } \\
\text { Quality Standards }\end{array}$} \\
\hline \multicolumn{5}{|c|}{ A is Sample 1 (Radial Street) } \\
\hline \multicolumn{5}{|c|}{ B is sample 2 (Creek sekanak river) } \\
\hline
\end{tabular}

\section{DISCUSSION}

Naturally, river ecosystems have a natural recuperation capacity (purification) to eliminate all pollutants that enter the river. However, this purification ability is very dependent on the intensity of pollutants from the surrounding environment. If the input materials of the surrounding environment liquefaction continue translating ongoing then purifying power of the river is not going to keep pace with the pollution[12] load. The result is that even though the river has purification capabilities, the water quality will continue to deteriorate [13].

The wastewater that has been treated is inseparable from the residue or residue that contains hazardous materials for aquatic life. Inorganic pollutants entering the waters from several industrial activities, community activities and natural resources, generally affect water quality. Accumulation of waste in the drain will become a large amount of waste and will affect the physical and chemical quality of water, for this reason, a study need to see how much the decline in water quality see from the physical and chemical parameters. [14]. Therefore, research to measure the physical and chemical quality of river water is an important activity at this time.

Palembang was once dubbed venice from the east because it made the river a means of transportation and community economic activity. Based on this history, the city government of Palembang plans to restore the function of rivers by normalizing and restoring rivers in Palembang. This activity was initiated by restoring the Sekanank River with the aim of making this river a water tourism site [15].

Sekanak River is a musi river, which located in the city of Palembang with a total flow area of $11.40 \mathrm{~km}^{2}$. This river is part of a drainage system consisting of nineteen systems that exist in the city area of Palembang [16]. Sekanak River has an estuary in the

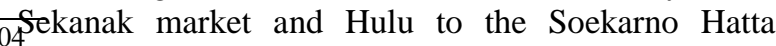
Street. Based on field surveys in this study, Sekanak er is located between the centres of human activities ranging from housing, shops, and hotels to

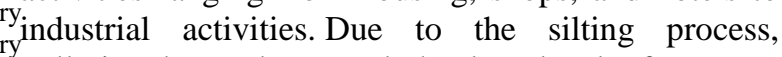
pollution by garbage and the low level of concern from the residents, the condition of the Sekanak River looks dirty and the water is brownish.

The quality of water for the parameter describes the amount of oxygen dissolved in water that is comparable to the speed of the metabolic activity of microorganisms [17]. The temperature of a body of water is influenced by the season, latitude, altitude from sea level, time of day, air circulation, cloud cover, flow and depth of water bodies. Temperature changes affect the physical and chemical processes of water bodies. The water temperature measured in this study was a bit high due to the river's condition which is more open and allows higher sunlight interaction.

The high Total Suspended Solid (TSS) content illustrates the presence of soil particles that accumulate in the waters. Dust, soil particles from the mining process, siltation can also cause high TSS content [18], while for total dissolved solids (total dissolved solids /TDS) consists of compounds organic and inorganic soluble in water, minerals and salts [19]. In this study the TSS and TDS content of upstream water samples were higher than those in the downstream and exceeded the permitted quality standard which indicates that upstream areas had more sources of organic-inorganic waste because they were passing through densely populated housing.

The degree of acidity $(\mathrm{pH})$ is the negative logarithm of the concentration of hydrogen ions released by a solutions and the high level of these ions in the waters is a bad indicator of the quality of the water. This $\mathrm{pH}$ used to measure water stability. [20]. A good pH level is a $\mathrm{pH}$ level, which still allows biological life in the water to run well. A good $\mathrm{pH}$ for water is neutral $(\mathrm{pH}=7)$.

Based on the results of this study indicate that the acidity of the upstream sample is lower than the downstream water sample. Upstream water samples also exceed the allowable $\mathrm{pH}$ limit of 5.2. This will disturb the growth of microorganisms in upstream waters and thought to cause by the large potential of 
organic waste in the form of phosphates and nitrates, which causes a decrease in water $\mathrm{pH}$.

This is according to research [21] states that the acidity level of waters in each microorganism is different but usually in the range of $6.5-8.5$. The acidity level of food water is generally high and fluctuating. This occurs because of the formation of acidic compounds such as phosphate and nitrate, which reduce the acidity of river water. Phosphate and nitrate can enter the aquatic environment because they are close to human activities and agriculture [22].Iron or ferrum $(\mathrm{Fe})$ is a silvery white metal, clay and can be formed. Iron in nature is obtained in the form of Hematite. The presence of iron in water is dissolved and can cause the water to turn yellowish red, giving off a fishy odor and forming a layer like oil. The presence of iron in water can also cause water to have colour, smell and taste [23]. From the research results, the upstream iron $(\mathrm{Fe})$ metal content of water samples is higher than downstream and exceeds the quality standard of $0.3 \mathrm{mg} / \mathrm{L}$. The excess iron content in water causes odor, taste and causes the water to turn yellowish.

Toxic metals for humans are obtained from various sources such as industrial waste, household waste such as plastic and rotting piles of waste that are dumped directly into waters such as rivers. In this study, measuring 3 heavy metals namely metal content of Manganese (Mn), Iron (Fe), Zinc ( $\mathrm{Zn}$ ) and Lead $(\mathrm{Pb})$. The highest content of manganese metal is $0.12 \mathrm{mg} / \mathrm{L}$ and the allowable limit is $0.2 \mathrm{mg} / \mathrm{L}$. The highest iron $(\mathrm{Fe})$ content is $0.45 \mathrm{mg} / \mathrm{L}$ and the allowable limit is $0.3 \mathrm{mg} / \mathrm{L}$. The highest zinc $(\mathrm{Zn})$ metal content is $0.001 \mathrm{mg} / \mathrm{L}$ and the highest permitted limit is $0.005 \mathrm{mg} / \mathrm{L}$. For Lead $(\mathrm{Pb})$ the highest content is $0.085 \mathrm{mg} / \mathrm{L}$ with an allowable limit of $0.03 \mathrm{mg} / \mathrm{L}$. From the results of this study, it can be seen that there are two metal parameters that exceed water quality standards, namely iron and lead metal parameters. Both of these parameters are found in water samples in the Upper.

The content of heavy metals that exceed water quality standards need to be aware that heavy metals can cause health problems for the body. Lead $(\mathrm{Pb})$ is very dangerous for humans because the mechanism of lead entry into the body can be through the respiratory system, digestion or directly through the surface of the skin. Lead poisoning can cause inflammation in the mouth, cause diarrhea, also cause anemia, nausea and abdominal pain and paralysis [24]. Lead can inhibit growth, decrease IQ, hyperactivity and mental disorders of children. Whereas in plants or plants, lead inhibits the speed of growth. Plant growth becomes stunted and chlorosis occurs in the leaves, which ultimately decreases agricultural production [25]. The effects of sulfate levels on heavy metal release were systemically investigated. Heavy metal releases of $\mathrm{Mn}, \mathrm{Ni}, \mathrm{Cu}, \mathrm{Pb}, \mathrm{Cr}$ and As could be rapidly triggered by sulfate addition but the releases slowly decreased over time [26].

Nitrate ions $\left(\mathrm{NO}_{3}-\mathrm{N}\right)$ are a common form of nitrogen compound found in natural waters. Denitrification under anaerobic conditions will result in a reduction reaction to nitrite $\left(\mathrm{NO}_{2}-\mathrm{N}\right)$ and ammonia $\left(\mathrm{NH}_{3}\right)$. Nitrite ions quickly oxidize to nitrate ions. Nitrite is a form of nitrogen that is only partially oxidized. Nitrite is not found in wastewater are fresh but in the long waste [27].

The content of ammonia $\left(\mathrm{NH}_{3}\right)$ in water is a global concern because of its very dangerous effects [28]. High ammonia content can cause a high number of fish deaths [29], increase white spot infections in fish [30], triggering damage to DNA levels for shrimp groups after exposure to ammonia for 48 hours. [17]. Ammonia content tends to be higher in summer. [31]. High levels of total ammonia in waters are thought to have originated from settlement waste and human animal disposal in the form of urine. Ammonia compounds naturally in the waters can also come from animal metabolism and the result of decomposition of organic matter by bacteria. High levels of ammonia indicate high pollution of organic matter. [32].

Based on the results of this study the levels of nitrite and nitrate in the water sample did not exceed the water quality standard that is with the highest levels of $0.02 \mathrm{mg} / \mathrm{L}$ for $\mathrm{N}$ as nitrite and $8 \mathrm{mg} / \mathrm{L}$ for $\mathrm{N}$ as Nitrate. It can be concluded that the $\mathrm{N}$ content in the water sample meets the acceptable limit. This examination is carried out because $\mathrm{N}$ compounds in the form of Nitrite, ammonia and nitrates in large quantities can cause Methemoglobinemia, namely the condition of Hemoglobin in the blood turned into methemoglobin so that the blood lacks oxygen and is known as " baby blues "[33].

\section{CONCLUSION}

The chemical and physical quality of water the Sekanak River on several parameters exceeds the limited threshold value. An increase in pollutant content in water after flowing from the creek into the river flow. Parameters that exceed the quality standard are TSS, TDS, Fe, Sulfate and Lead. Sekanak river revitalization program must pay attention to quality factors for the sustainability of the Sekanak river ecosystem. 


\section{ACKNOWLEDGMENT}

This research was fully supported and funded by Department of Medical Laboratory Technology, Faculty of Health Science, Musi Charitas Catholic University, Palembang, Indonesia. Especially for Dean Faculty of Health Science, Mrs. Maria Nur Aeni, M.Kes.

\section{REFERENCES}

Said M, Nasir S, Priadi DP. The Effect of Pressure and Time Operation of Gasing River Water Treasure on Pollutant Concentration by Using Ceramic Membrane Separation. Sriwij J Environ 2018;3:47-54. https://doi.org/10.22135/sje.2018.3.2.47-54.

[2] Tumbuhan I, Di O, Raya K, Dan S, Desa P, Kabupaten B, et al. IDENTIFICATION OF MEDICINAL PLANTS IN SRIWIJAYA BOTANICAL 2019;2:102-7.

[3] Arita S. 5. Charact. Bentonite Jocet- naswir 2020.

[4] Aryansyah, Ibrahim E, Nasir S, Said M, Kurniawan I, Huda A. A new prototype design and experimental study for assessing spontaneous coal combustion. J Ecol Eng 2019;20:9-17. https://doi.org/10.12911/22998993/108682.

[5] Kementerian Pertanian. Panduan Pengelolaan Berkelanjutan Lahan Gambut Terdegradasi. 2014.

[6] Setiawan AA, Emilia I, Suheryanto. Kandungan merkuri total pada berbagai jenis ikan. Semin Nas Sains Teknol V 2013:741-50.

[7] Bahtiar A. Polusi Air Tanah akibat Limbah Industri dan Rumah Tangga serta Pemecahannya. Univ Padjajaran 2007; 10:246-54.

[8] Marfai MW dan MA. Kajian daya tampung sungai gajahwong thdp beban pencemaran. Maj Geogr Indones Vol 18, No 2, Sept 2004, Hal 81-97 2004:81-97.

[9] Azwir. Analisa Pencemaran Air Sungai Tapung Kiri Oleh Limbah Industri Kelapa Sawit 2006.

[10] Prayogo TB. Analisis Kualitas Air Dan Strategi Pengendalian Pencemaran Air Sungai Blukar Kabupaten Kendal. J Presipitasi 2012;9:64-71-71. https://doi.org/10.14710/presipitasi.v9i2.64-71.

[11] Pohan DAS, Budiyono B, Syafrudin S. Analisis Kualitas Air Sungai Guna Menentukan Peruntukan Ditinjau Dari Aspek Lingkungan. J Ilmu Lingkung 2017;14:63. https://doi.org/10.14710/ji1.14.2.63-71.

[12] Kurniawan I, Mariadi PD. Analisis Potensi Cemaran Sisa Penggunaan Antibiotik di Perairan Umum (Studi Kasus : Badan Sungai Musi Kota Palembang). Sainmatika J Ilm Mat Dan Ilmu Pengetah Alam 2019;16:110. https://doi.org/10.31851/sainmatika.v16i2.3176.

[13] Ujati ADBAS, Riyono AGUSP, Iti DANS. Water Quality Characteristic of Ciliwung River at Bogor Botanical Garden Segmen, Bogor. Water Qual Charact Ciliwung River Bogor Bot Gard Segmen, Bogor 2017;22:111-7. https://doi.org/10.29244/medkon.22.2.111-117.

[14] Riena NN, Ayu W, Putri E, Agustriani F. Analisis Kualitas Perairan Muara Sungai Way Belau Bandar Lampung. / Maspari J 2012;04:116-21.

[15] Inge N. Sensasi Sarapan Pagi di Warung Apung Sungai Musi Palembang. 2019

[16] (BLH) Kota Palembang BLH. Laporan Sungai Anak Sungai Palembang 2012.

[17] Cheng CH, Ma HL, Su YL, Deng YQ, Feng J, Xie JW, et al. Ammonia toxicity in the mud crab (Scylla paramamosain): The mechanistic insight from physiology to transcriptome analysis. Ecotoxicol Environ Saf
2019;179:9-16

https://doi.org/10.1016/j.ecoenv.2019.04.033.

[18] Fatoki OS, Muyima NYO, Lujiza N. Situation analysis of water quality in the Umtata River catchment. Water SA 2001;27:467-73. https://doi.org/10.4314/wsa.v27i4.4959.

[19] Fardiaz S. Polusi Air dan Udara. 1992.

[20] In D, East THE, Waters B, Belitung B. Hubungan Faktor Lingkungan Kimia, Fisika Terhadap Distribusi Plankton Di Perairan Belitung Timur, Bangka Belitung. J Perikan Univ Gadjah Mada 2009;11:31-45. https://doi.org/10.22146/jfs.2970.

[21] Zinov'ev D V., Sole P. Quaternary codes and biphase sequences from Z8-codes. Probl Peredachi Informatsii 2004:40:50-62. https://doi.org/10.1023/B

[22] Chung O. Second edition. Taiwan Rev 2019;69.

[23] Munfiah S, Setiani O. Kualitas Fisik dan Kimia Air Sumur Gali dan Sumur Bor di Wilayah Kerja Puskesmas Guntur II Kabupaten Demak. J Kesehat Lingkung Indones 2013:12:154-9. https://doi.org/10.14710/jkli.12.2.154.

[24] Mariadi PD, Kurniawan IAN, Setiawan H. Lead and cadmium mobilization from anas moscha and cairina moschata tissue using pineapple extract as chelating agents. Pollut Res 2018;37:330-3.

[25] Zhang L, Xu EG, Li Y, Liu H, Vidal-Dorsch DE, Giesy JP. Ecological risks posed by ammonia nitrogen (AN) and unionized ammonia (NH3) in seven major river systems of China. Chemosphere 2018;202:136-44. https://doi.org/10.1016/j.chemosphere.2018.03.098.

[26] Sun H, Shi B, Yang F, Wang D. Effects of sulfate on heavy metal release from iron corrosion scales in drinking water distribution system. Water Res 2017;114:69-77. https://doi.org/10.1016/j.watres.2017.02.021.

[27] Ginting P. Sistem Pengelolaan Lingkungan dan Limbah Industri. 2007.

[28] Park TJ, Lee JH, Lee MS, Park CH, Lee CH, Moon SD, et al. Development of water quality criteria of ammonia for protecting aquatic life in freshwater using species sensitivity distribution method. Sci Total Environ 2018;634:934-40.

https://doi.org/10.1016/j.scitotenv.2018.04.018.

[29] Egnew N, Renukdas N, Ramena Y, Yadav AK, Kelly AM, Lochmann RT, et al. Physiological insights into largemouth bass (Micropterus salmoides) survival during long-term exposure to high environmental ammonia. Aquat Toxicol 2019;207:72-82. https://doi.org/10.1016/j.aquatox.2018.11.027.

[30] Lu X, Luan S, Dai P, Luo K, Chen B, Cao B, et al. Insights into the molecular basis of immunosuppression and increasing pathogen infection severity of ammonia toxicity by transcriptome analysis in pacific white shrimp Litopenaeus vannamei. Fish Shellfish Immunol 2019;88:528-39. https://doi.org/10.1016/j.fsi.2019.03.026.

[31] Wang X, Li J, Chen J, Cui L, Li W, Gao X, et al. Water quality criteria of total ammonia nitrogen (TAN) and unionized ammonia $(\mathrm{NH} 3-\mathrm{N})$ and their ecological risk in the Liao River, China. Chemosphere 2020;243. https://doi.org/10.1016/j.chemosphere.2019.125328.

[32] Effendi H. Telaah Kualitas Air bagi Pengelolaan Sumber Daya dan Lingkungan Perairan. 2003.

[33] . Soemirat.Kesehatan Lingkungan Yogyakarta. 2009. 